TEME, г. XLIV, бр. 2, април - јун 2020, стр. 607-620

\begin{tabular}{lr}
\hline \hline Оригинални научни рад & https://doi.org/10.22190/TEME190205042I \\
Примљено: 5. 2. 2019. & UDK 342.721 \\
Ревидирана верзија: 2. 4. 2020. & 341.231 .14 \\
Одобрено за штампу: 15. 4. 2020. &
\end{tabular}

\title{
DOES ARTICLE 2 OF THE EUROPEAN CONVENTION \\ ON HUMAN RIGHTS PRESCRIBE AN ABSOLUTE \\ PROHIBITION OF THE DEATH PENALTY? \\ THE IMPACT OF RECENT PRACTICE OF EUROPEAN COURT OF HUMAN RIGHTS
}

\author{
Ivan Ilić*, Saša Knežević \\ University in Niš, Faculty of Law, Niš, Serbia \\ *ivan@prafak.ni.ac.rs
}

\begin{abstract}
In paragraph 1 of Article 2 of the European Convention on Human Rights (ECHR), the imposition of the death penalty is permitted, as a departure from the right to life. In the last decades there has been a tendency for the absolute abolition of the death penalty, in times of war and peace. As a result of this effort, almost all European countries abolished the death penalty. In addition, the Council of Europe adopted Protocol 6 and Protocol 13, which completely abolished the death penalty. The European Court also, in its practice, using the principle of "convention as a living instrument", has changed its approach to the scope of the ban on the application of the death penalty. The authors deal with a critical interpretation of the case-law of the European Court of Human Rights, trying to answer the question, of whether there has been an abrogation of the provision of paragraph 1 of Article 2, so that according to that provision, there is an absolute ban on the application of the death penalty in the Council of Europe member states.
\end{abstract}

Key words: $\quad$ right to life, ECHR, ECtHR, death penalty, Protocol 6 and 13.

\section{ДА ЛИ ЧЛАН 2 ЕВРОПСКЕ КОНВЕНЦИЈЕ О ЉУДСКИМ ПРАВИМА ПРЕДСТАВЉА АПСОЛУТНУ ЗАБРАНУ СМРТНЕ КАЗНЕ? - УТИЦАЈ НОВИЈЕ ПРАКСЕ ЕВРОПСКОГ СУДА ЗА ЉУДСКА ПРАВА}

\section{Апстракт}

У ставу 1 члана 2 Европске конвенције за заштиту људских права (ECHR) је, као одступање од права на живот, допуштена примена смртне казне. Последњих деценија дошло је до тенденције за апсолутним укидањем смртне казне, у доба рата и мира. Као резултат тог настојања готово све европске државе су укинуле смртну казну. Уз то, Савет Европе је усвојио Протокол 6 и Протокол 13, којим 
је потпуно укинуо смртну казну. Европски суд је такође у својој пракси, користећи се начелом „конвенција као живи инструмент”, мењао приступ према опсегу забране примене смртне казне. Аутори се у раду баве критичким тумачењем праксе Европског суда, покушавајући да одговоре на питање да ли је дошло до аброгације одредбе става 1 члана 2, тако да сада и према тој одредби постоји апсолутна забрана примене смртне казне у државама чланицама Савета Европе.

Кључне речи: право на живот, ECHR, ECtHR, смртна казна, Протокол 6 и 13.

\section{INTRODUCTION}

Death penalty is, undoubtedly, the toughest criminal sanction. It derogates the most important human right, the right to life. The use of the death penalty undermines human dignity. Today there is a tendency in the world to abolish the death penalty which contributes to the enhancement and progressive development of human rights. In addition to the right to life, imposition of the death penalty derogates other rights relating to human dignity. Most often, the death penalty is associated with the right not to be subjected to torture or cruel, inhuman or degrading treatment or punishment, which has traditionally been depicted as at the core of the notion of human dignity. In this paper, the authors will deal with the impact of the movement to abolish the death penalty on the scope of the right to life. Bearing in mind that the tendency towards the gradual abolition of the death penalty stems from the United Nations approach, it is necessary to start from legal instruments of this organization and the practice of the courts under its auspices.

\section{DEATH PENALTY IN THE UN - NORMS AND PRACTICE}

From the early 1960s, when a majority of countries still used the death penalty, the draftees of the International Covenant on Civil and Political Rights (ICCPR) had already begun moves for its abolition. Article 6 of the ICCPR permits the use of the death penalty in limited circumstances. In par. 2 of Article 6 ICCPR is prescribed "in countries which have not abolished the death penalty, sentence of death may be imposed only for the most serious crimes in accordance with the law in force at the time of the commission of the crime and not contrary to the provisions of the present Covenant and to the Convention on the Prevention and Punishment of the Crime of Genocide. This penalty can only be carried out pursuant to a final judgment rendered by a competent court". It is clear that imposition of the death penalty is limited to "most serious crimes" However, it also provides that "nothing in this article shall be invoked to delay or to prevent the abolition of capital punishment by any State Party to the present Covenant." Also, in theory, there has been the opinion that the death sentence is a sanction which is contrary to the protection of human's right. In 1962, Marc Ancel, in his study Capital punishment, stated that the 
death penalty was a form of cruel and inhuman punishment (Ancel, 1962, p. 227). Amnesty International played an important role in the abolition of the death penalty. In 1977, this NGO convened a major international conference to promote the abolition of the death penalty and a moratorium on the already imposed sentences. Amnesty International had no hesitation in invoking both the right to life and the prohibition of cruel and inhuman punishment. Amnesty International later lobbied strongly for the adoption of the ECHR Protocol, which abolishes the death penalty.

Later, in 1984, the UN Economic and Social Council adopted Safeguards for protection of the rights of those facing the death penalty. In 1989, UN General Assembly adopted the Second Optional Protocol to the ICCPR, and Member States which became parties to the Protocol agreed not to execute anyone within their jurisdictions. There was no obligation for states to abolish the death penalty, but to subject that sanction to certain restrictions. It was stated that abolition is a progress in the enjoyment of the right to life (Rodley, 2015, p. 208). In a series of four resolutions adopted in 2007, 2008, 2010, 2012 and 2013, the General Assembly urged the States to respect international standards, that protect the rights of those facing the death penalty, to progressively restrict its use and reduce the number of offences which are punishable by death. In resolutions there also was request for states to establish a moratorium on executions.

The United Nations Human Rights Council (UNHRC) in Resolution 2005/59 called upon all states that still maintain the death penalty to abolish it completely and, in the meantime, to establish a moratorium on executions. In addition, the UNHRC has called for the commutation of the death sentences of all prisoners whose final appeals have been exhausted in a country where no executions had been carried out for more than 10 years (Concluding observations of the Human Rights Committee: Kenya, UN document CCPR/CO/83/KEN, 2005). In resolution 32/61, the UN General Assembly (UNGA) stated that the main objective to be pursued in the field of capital punishment is that of progressively restricting the number of offences for which the death penalty may be imposed. The UNHRC has stated that extension of the scope of application of the death penalty is not compatible with Art.6 of the ICCPR (Concluding observations of the Human Rights Committee: Peru, UN document CCPR/C/79/Add.67, 1996).

UN General Comment No.6 on Art.6 of ICCPR proscribes that the expression "most serious crimes" in Art.6 (2) of ICCPR must be read restrictively to mean that the death penalty should be a quite exceptional measure (General Comment 6 on Article 6 of the International Covenant on Civil and Political Rights, 1982). Also, as the UN Human Rights Committee held, applying the death penalty in response to a crime not constituting the most serious crime would violate both the right to life and the right to freedom from torture guaranteed under Art.6(2) and Art.7 of the ICCPR (Human Rights Committee, General Comment, No. 36, 2018). The UNHRC 
has stated that the expression "most serious crimes" must be read restrictively to mean that the death penalty should be a quite exceptional measure. Also, applying the death penalty in response to a crime not constituting the most serious crime would violate both Art.6 (2) and Art.7 of the ICCPR. At last, UNHRC holds that States parties may not transform an offence, which upon ratification of the ICCPR, or at any time thereafter, did not entail the death penalty, into a capital offence.

UN's Safeguards guaranteeing the protection of the rights of those facing the death penalty exclude the possibility of imposing death sentences for crimes of religious or political nature, including acts of treason, espionage and other vaguely defined acts usually described as crimes against the State (Report of the Special Rapporteur on extrajudicial, summary or arbitrary executions, UN document E/CN.4/1999/39). General Comment no.36 on Art.6 of ICCPR states that "crimes not resulting directly and intentionally in death, although serious in nature, can never justify the imposition of the death penalty". In resolution 2005/59, the UNCHR urged all states that still maintain the death penalty to ensure that the death penalty is not imposed for non-violent acts such as financial crimes, religious practice or expression of conscience. The term "most serious crimes" must be read restrictively and appertain only to crimes of extreme gravity (Chisanga v. Zambia, Comm. 1132/2002, U.N. Doc. A/61/40). Crimes not resulting directly and intentionally in death (Concluding Observations: Iran, 1993, para. 8) such as drug offences (Concluding Observations: Thailand, 2005, para. 14), or abduction and sexual offences (Concluding Observations: Guatemala, 2001, para. 17), although serious in nature, can never justify, the imposition of the death penalty. Also, The UN Special Rapporteur has stated that the death penalty should be eliminated for crimes such as drug-related offences (Report of the Special Rapporteur on the extrajudicial, summary or arbitrary executions, UN document E/CN.4/1997/60). The UNHRC has stated that economic offences, including embezzlement by officials and political offences cannot be characterized as the most serious crimes under Art.6(2) of the ICCPR and that the imposition of the death penalty for these offences therefore violates that article (Concluding observations of the Human Rights Committee: Libyan Arab Jamahiriya, UN document CCPR/C/79/Add.101, para. 8). Also, Art.4(4) of the ACHR states: "In no case shall capital punishment be inflicted for political offences or related common crimes".

In all cases involving the application of the death penalty, the personal circumstances of the offender and the particular circumstances of the offence, including its specific attenuating elements, must be considered by the sentencing court (Lubuto v. Zambia, Comm. No. 390/1990, U.N. Doc. CCPR/C/55/D/390/1990). UNHRC held that those who have refused to obey orders, regarding torture, inhuman or degrading treatment, must not be punished or subjected to any adverse treatment. The imposition of such a punishment is contrary to all above-mentioned principle. Finally, States 
should also refrain from executing individuals who have suffered in the past serious human rights violations, such as torture victims (Pratt and Morgan v Jamaica, Communication No. 210/1986).

The UNHRC stated that the imposition of death sentence after a trial, where the provisions of the ICCPR have not been respected, was a violation of Art.6 of the ICCPR (Khalilova v. Tajikistan, Comm. 973/2001, U.N. Doc. A/60/40). In Reid v. Jamaica, UNHRC explicitly stated that there is a violation of Article 6 of ICCPR if provisions of Covenant have not been respected in proceedings where the death penalty has been imposed. Minimal guarantees in the proceedings are right to a fair trial before independent tribunal, presumption of innocence, right to defense and right to appeal (Carlton Reid v. Jamaica, Communication No. 250/1987, U.N. Doc. CCPR/C/39/D/250/1987). Similar ascertainment has been given by Inter-American Court in the case of Hilaire, Constantine and Benjamin et al. v. Trinidad and Tobago, where it is highlighted that guarantees from due process are the most important when human life is at stake (Hilaire, Constantine and Benjamin et al. v. Trinidad and Tobago, case 12.269, par. 146). The rights of anyone charged with a crime for which capital punishment may be imposed to adequate legal assistance at all stages of the proceedings, goes above and beyond the protection afforded in non-capital cases (Implementation of the safeguards guaranteeing protection of the rights of those facing the death penalty, Resolution 1989/64). For example, violation of Art. 14 of the ICCPR would occur in cases of inadequate legal representation (Saidova v. Tajikistan, Comm. 964/2001, U.N. Doc. A/59/40), or trial before a military court (Kurbanova v. Tajikistan, Comm. 1096/2002, U.N. Doc. A/59/40).

Art. 14 (5) of the ICCPR states that everyone convicted of a crime shall have the right to his conviction and sentence being reviewed by a higher tribunal according to law. The UNHRC has stated that the imposition of death sentences without the possibility of appeal is incompatible with the ICCPR (Concluding observations of the Human Rights Committee: Uganda, $\mathrm{UN}$ document CCPR/CO/80/UGA, para. 13), and would represent a violation of the right to life in death penalty cases. Also, proceedings must guarantee the right of review of both actual and legal aspects of the case by a higher tribunal (Report of the Special Rapporteur on the extrajudicial, summary or arbitrary executions, UN document E/CN.4/1997/60).

\section{THE EUROPEAN CONVENTION AND DEATH PENALTY}

Article 2 of the Convention guarantees the right to life, one of the most fundamental provisions and absolute right, without exceptions or provisions, or the possibility of derogation (Pretty v. The United Kingdom, no. 2346/02 §49). In article 2 of the Convention is stated that "Everyone's right to life shall be protected by law. No one shall be deprived of his life 
intentionally save in the execution of a sentence of a court following his conviction of a crime for which this penalty is provided by law. Deprivation of life shall not be regarded as inflicted in contravention of this article when it results from the use of force which is no more than absolutely necessary: (a) in defense of any person from unlawful violence; (b) in order to effect a lawful arrest or to prevent the escape of a person lawfully detained; (c) in action lawfully taken for the purpose of quelling a riot or insurrection." The protection of the right to life includes the duty to refrain from unlawful taking of life (negative obligation), and the duty to provide an adequate legal framework protecting the right to life, and to take positive steps to prevent the violation of the right to life (positive material obligation) and to carry out and effective official investigation when an individual has been killed as a result of the use of force or other fatal incidents (positive procedural obligations).

The first exception to right to life concerning the death penalty, is expressly permitted by the original text of Article 2 (1) of the European Convention on Human Rights. The use of the death penalty had to be allowed back when the Convention was drafted. This is due to the fact that, at that time, in the 1950, capital punishment was generally provided for and applied in Western Europe. The possibility of imposing the death penalty provided when the European Convention on Human Rights (ECHR) opened for signature in 1950 (Article $2 \S 1$ : "No-one shall be deprived of his life intentionally save in the execution of a sentence of a court following his conviction of a crime for which this penalty is provided by law"). In Europe since the late 1960s, consensus has been slowly emerging that the death penalty is unacceptable in civilized society and is incompatible with the rule of law and respect for human rights. The first legally binding instrument providing for the unconditional abolition of the death penalty during peacetime, Protocol no. 6 of the ECHR, was adopted by the Council of Europe in 1983. The Protocol is currently ratified by 46 of the 47 Council of Europe member states. In October 1997 the Council of Europe Heads of State and Government called for the "universal abolition of the death penalty". Resolution II adopted at the European Ministerial Conference on Human Rights on 3 to 4 November 2000 invited the Committee of Ministers "to consider the feasibility of a new additional protocol to the Convention, which would exclude the possibility of maintaining the death penalty in respect of acts committed in time of war or of imminent threat of war". Protocol no. 13 with the ECHR, adopted by the Council of Europe in 2002, abolished the death penalty in all circumstances, both in times of war or imminent threat of war. The Protocol entered into force on 1 July 2003. It is not possible to derogate from this, nor can the States put reservations into its implementation. The Protocol has so far been ratified by 42 Council of Europe member states and signed in 3 more countries. Thanks to the legal and political mechanisms in place, the process of complete abolition of the death penalty is irreversible. The case law of the European Court of Human 
Rights shows that the Court has also recognized the development of the legal status of the death penalty.

Accordingly, the wording of Art.2 explicitly permits capital punishment in those states which have not abolished it, either by domestic legislation, or by the ratification of Protocol 6 and 13 to the Convention. However, the practice has changed radically since, right to the point where the Council of Europe has become an almost death penalty free zone. The 6th Protocol to the Convention requires the abolition of death penalty in peacetime, while this partial prohibition was made total by the 13th Protocol which requires the abolition of capital punishment in the time of war as well. However, Art. 2 remains the governing provision for the State parties to the Convention who are not parties to these Protocols.

\section{THE EVOLUTION OF THE EUROPEAN COURT OF HUMAN RIGHTS PRACTICE}

The first significant case, which concerned with death penalty was Soering v United Kingdom (Soering v. the United Kingdom, app. no. 14038/88). It was about the potential extradition of the applicant to the USA by the UK of a West German national to face trial in Virginia on a murder charge. The applicant argued that if he were found guilty of murder and sentenced to death, that he would experience the 'death row-phenomenon' which would lead to the violation of his rights, provided in the Convention.

Jens Soering is a German national, who at the time of the alleged offence was a student at the University of Virginia. He and his girlfriend were wanted in Virginia for the murder of his girlfriend's parents. The couple disappeared from Virginia in October 1985, and later were arrested in England for committing another offence. Soering was interviewed by police in the UK, which led to his indictment on charges of capital murder. The USA started extradition proceedings with the UK, under the Extradition Treaty between the USA and UK. The applicant applied to the European Court on Human Rights (ECtHR) alleging the breach of Article 3, 6 and 13 ECHR.

In Soering v. the UK European Court held that it would have been possible for the parties to the Convention to have abrogated the exception provided for in Article 2(1) by generalized abolition of capital punishment in their national law and practice. Nevertheless, given the case was decided only 6 years after the adoption of 6th Protocol, the Court considered that this had not occurred at the time. The Court in this case highlighted that the Convention is a living instrument which must be interpreted in the light of present-day conditions. It was also stated that de facto there was no longer death penalty in the peacetime. But, the Court pointed out that there was no intention of the drafters of the Convention to include a general prohibition of the death penalty, since that would nullify the clear wording of Article 2 
$\S 1$ (art. 2-1). Finally, the Court stated that the general abolishment of the death penalty could be established as an agreement of the states to abrogate an exemption from the article 2 par 1 of the Convention. However, the Court claimed that the adoption of Protocol 6 shows that Contracting States chose the method for abolishing the death penalty. Thus, the Court concluded that there is no prohibition of the death penalty in the text of the Convention. States that intend to expel a person must require strong assurances from the United States and other retentionist countries that those extradited or expelled will not be sentenced to death. (Soering v. the United Kingdom, app. no. 14038/88). The Court added that imposition of the death penalty may give rise to an issue under Article 3 of the Convention. It refers to the method of imposition or execution, personal circumstances of condemned person, disproportionality of the sanction with the crime committed and condition in detention.

Having in mind the abolitionist trend in Contracting states, in the period that follows, the question about the death penalty again was the topic before the Court in the case of Ocalan $v$ Turkey. The applicant had been detained in Kenya. He had allowed himself to be taken by Kenyan officials to the Nairobi airport in the belief that he was free to leave for a destination of his choice, but they took him to an aircraft in which Turkish officials were waiting for him and he was arrested after he had boarded the aircraft. In this case, the applicant requested from the Court to conclude that the States had abrogated from of the provision in Article $2 \S 1$ of the Convention, and that the death penalty constituted inhuman and degrading treatment within the meaning of Article 3 (Ocalan v Turkey, app. no. 46221/99, § 157). The Court firstly called in the case of Soering, and repeated the statement that Article 2 of the Convention permit the death penalty, and that in Article 3 there is no prohibition of the death penalty. However, the Court recognized changes in the Contracting States after the decision in Soering cases. Namely, at that time forty-one State ratified Protocol 6, which means that there is almost complete prohibition of the death penalty in the peacetime, excluding Turkey, Armenia and Russia. Such occasion leads to the conclusion that there is an agreement between Contracting States to modify Article 2 par. 1 of the Convention. The court asks the question, if it is necessary to wait for the three remaining states to ratify Protocol 6, to conclude that Article 2 has been modified. The Court explicitly stated that capital punishment in peacetime is unacceptable under Article 2 (Ocalan v Turkey, app. no. 46221/99, § 163). Grand Chamber in the case of Ocalan partly dissociated from the chamber statement. It stated that Contracted States choose other way to amending the Convention, by the adoption of Protocol 13, which completely prohibits death penalty. Grand Chamber found unnecessary to conclude about the abrogation of the Article 2, stated that it would be contrary to the Convention, to implement the death sentence following an unfair trial. 
Additionally, this matter was considered again in Al-Saadon and Mufdhi $v$ the UK. This case concerns a complaint by two Iraqi nationals that the British authorities in Iraq had transferred to Iraqi custody in breach of an interim measure indicated by the European Court under Rule 39 of the Rules of Court, so putting them at the real risk of an unfair trial followed by execution by hanging (Al-Saadon and Mufdhi v the UK, app. no. 61498/08). The Court pointed out that by the adoption of Protocol 13 there has been an evolution toward de iure abolition of the death penalty in any occasion. The Court further stated that all of member States ratified Protocol 6, and that in the Council of Europe there was initiative for "universal abolition of the death penalty". The Court concluded that the situation evolved from the time when the Court decided in the case of Ocalan. The Court explicitly stated that, bearing in mind that two of Contracting States only signed Protocol 13, there is consistent practice of moratorium to the death sentence. It can be concluded that Article 2 is now amended as to prohibit the death sentence in any circumstances. It is interesting that the Court pronounced such a claim at a time when several states had never ratified Protocols 6 and 13 (Harris, O'Boyle, Ed Bates, Buckley, 2014, p. 226). Finally, the Court stated that Article $2 \S 1$ is no longer a bar to its interpreting the words "inhuman or degrading treatment or punishment" in Article 3 as including the death penalty (Al-Saadon and Mufdhi v the UK, app. no. 61498/08, § 120). Thus, the court has established an evolved Article 3 threshold. Since the Court has found that Article 2 has been amended, the application of the death penalty is itself considered to be a violation of Article 3 (Behrmann, Yorke, 2013, p. 22).

The second group of cases include those in which the Court considered the violation of Article 2 of the Convention, due to the applicant's deportation to a State in which he was threatened with the imposition and execution of the death penalty. In general, the Court does not rule out the possibility of violating Article 2 of the Convention in cases of deportation of an alien to a State in which are threatened with the imposition of the death penalty (S.R. v. Sweden (dec.), app. no. 62806/00, Ismaili v. Germany (dec.), app. no. 58128/00, Bahaddar v. the Netherlands, app. no 25894/94, §§ 75-78). A violation of Article 2 of the Convention may also occur in the case of the imposition of the death penalty after an unfair proceeding. In the case of Bader and Cambor in Sweden, it was concluded that the expulsion of the applicant in Syria would constitute a violation of Articles 2 and 3 of the Convention, because of the summary nature and total disregard for the rights of defense in the proceedings before Syrian authorities that must be regarded as a flagrant denial of a fair trial (Bader and Kanbor, app. no. 13284/04, § 42). If we carefully analyze the position of the Court in this case, we note that the key argument is the reasonable belief that the applicant will be subjected to the death penalty, and therefore, fear and anguish arise in him. However, fear and anguish are 
constitutive elements for the violation of Article 3 and the Court finds that the expulsion would lead to a violation of Article 2. For the violation of Article 2, the existence of the risk to life is necessary. Therefore, although the Court contends otherwise, the risk to life, in the case of expulsion, is just the basis for a violation of Article 2. If there is a risk to life (due to the death penalty), then the existence of a violation of Article 2 should be established, and if there is a risk of torture or inhuman or degrading treatment, then the Court should establish a violation of Article 3 of the Convention. The Court is approaching such a position in the case of $\mathrm{Al}$ Nashiri v Poland. The Court found a violation of Article 2, together with Article 1 of Protocol No. 6, as a violation of Article 3 of the Convention. The Court observed that the execution of the death penalty, regardless of the method of execution, constitutes the premeditated destruction of a human being by government bodies. Regardless of the manner of execution, deprivation of life causes physical pain. In addition, the realization that death is coming, on the side of a person in the hands of the State, inevitably produces intense psychological suffering. The Council of Europe member states have recognized the fact that the imposition and use of the death penalty denies basic human rights. In the Preamble to Protocol No. 13 the Contracting States describe themselves as "convinced that everyone's right to life is a basic value in a democratic society and that the abolition of the death penalty is essential for the protection of this right and for the full recognition of the inherent dignity of all human beings" (Al Nashiri v. Poland, app. no. 28761/11 § 577).

Moreover, the imposition of the death sentence on a person after an unfair trial would generate, in circumstances where there exists a real possibility that the sentence will be enforced, a significant degree of human anguish and fear, bringing the treatment within the scope of Article 3 of the Convention. The Court has also acknowledged that an issue might exceptionally be raised under Article 6 of the Convention by an extradition decision in circumstances where the fugitive has suffered or risks suffering a flagrant denial of a fair trial in the requesting country (Mamatkulov and Askarov v. Turkey [GC], app. nos. 46827/99 and 46951/99, § 88, Soering v. the United Kingdom, app. no. app. no. 14038/88, § 113). However, if the state has obtained a firm guarantee that the applicant will not be subjected to the death penalty, the risk is eliminated, and the application will be rejected as manifestly ill founded (Einhorn v France, app. no. 71555/01 (dec.). In such cases, the Court appreciates the quality of the guarantees provided. In principle, in international relations, diplomatic notes carry a presumption of good faith. The Court considers that, in extradition cases, it is appropriate that that presumption be applied to a requesting State which has a long history of respect for democracy, human rights and the rule of law, and which has longstanding extradition arrangements with the Contracting States. The assurances given must be specific, clear and 
unequivocal (Rrapo v Albania, app. no. 58555/10, §72,73). In the case of Demir v Turkey, the Court also pointed out that the applicant's unfounded fear of the reaffirmation of the death penalty was not sufficient to violate Article 3 of the Convention. In this case, the submission of the applicant was also dismissed as manifestly ill-founded (Demir v Turkey, app. no. 55373/00 (dec.).

According to the Courts case law, it can be concluded that the penalty for the crime must be provided by law, which is accessible and foreseeable. The death penalty should be permissible only for "the most serious crimes". A death sentence should be imposed only by the independent and impartial tribunal, in the sense of Article 6 of the Convention, and in the proceedings which fulfill all of the standards of fairness.

\section{CONCLUSION}

The relentless trend of universal abolition of the death penalty has, in recent decades, been reflected in the growing number of international and national legal instruments adopted, as well as in the increasing recognition by state governments that the death penalty has no place in the contemporary democratic society. Although abolition of the death penalty is not expressly required, the prohibition of the death penalty is established under the Second Optional Protocol to the ICCPR aiming at the abolition of the death penalty, Protocol No. 6 ECHR concerning the abolition of the death penalty in the peacetime, Protocol No. 13 concerning the abolition of the death penalty in all circumstances and the Second Protocol to the American Convention on Human Rights to Abolish the Death Penalty. Following the reasoning of the ECtHR, we argue that at the present time it could be said that capital punishment is in itself a breach of the right to life, guaranteed under Article 2 of the Convention, regardless of whether a particular State ratified Protocol 13. It could be said that Article 2 of the Convention has been amended so as to prohibit the death penalty in all circumstances. In support of that claim, comes the Council of Europe's General Secretary statement from July 2016. He made clear, at the time when Turkey was striving to reintroduce the death penalty for terrorists and murderers of women and children, that, in accordance with the duties and obligations of the state, they should not under any circumstances derogate Article 2 of the Convention (Exchange of views on the question of abolition of capital punishment, Human Dimension Implementation Meeting, 2017). This means that capital punishment in any form is now a violation of the right to life. In addition, the imposition of the death penalty is undoubtedly contrary to the prohibition of torture, inhuman and degrading treatment. Together with the abrogation of Article 2 of the Convention, there is an evolution of the concept of the right to life on the international level. This evolution goes to the maxims that the right to life cannot be taken away intentionally, unless in this way the right to life of the 
other is saved. This concept is referred to in literature as "protect life" (Heyns, Probert, 2015, p. 215-216). Such a trend, through international regulations, imposes an obligation for states to abolish the death penalty. This position has been reinforced by important initiatives, taken by regional organizations, which can play a significant role in the promotion and protection of the right to life around the world.

\section{REFERENCES}

Al Nashiri v Poland, app. no. 28761/11;

Al-Saadon and Mufdhi v the UK, app. no. 61498/08,

Al-Saadon and Mufdhi v the UK, app. no. 61498/08;

Ancel, M, (1962) Capital Punishment, New York, United Nations, Department of Economic and Social Affairs;

Bader and Kanbor, app. no. 13284/04;

Bahaddar v. the Netherlands, app. no 25894/94;

Barno Saidova v. Tajikistan, Communication No. 964/2001;

Behrmann, C, Yorke, J, (2013) The European Union and abolition of the death penalty, Pace International Law Review Online Companion, 4(1), 1-78;

Capital Punishment, UN General Assemby A/RES/32/61 (1977);

Chisanga v Zambia, Communication No. 1132/2002;

Concluding observations of the Human Rights Committee: Kenya, UN document CCPR/CO/83/KEN, (2005);

Concluding observations of the Human Rights Committee: Libyan Arab Jamahiriya, UN document CCPR/C/79/Add.101, (1998);

Concluding observations of the Human Rights Committee: Peru, UN document CCPR/C/79/Add.67, (1996);

Concluding observations of the Human Rights Committee: Sudan, UN document CCPR/C/79/Add.85; (1997);

Concluding observations of the Human Rights Committee: Uganda, UN document CCPR/CO/80/UGA, (2003);

Concluding Observations: Guatemala, UN document CCPR/CO/72/GTM, (2001);

Concluding Observations: Iran, UN document CCPR/C/79/Add.25, (1993);

Concluding Observations: Thailand, UN document CCPR/CO/84/THA, (2005);

Demir v Turkey, app. no. 55373/00 (dec.),

Einhorn v France, app. no. 71555/01 (dec.);

General comment No. 36 (2018) on article 6 of the International Covenant on Civil and Political Rights, on the right to life, (CCPR/C/GC/36), (2018);

Harris, D, O'Boyle, M, Bates, E, Buckley, C, (2014) Law on the European Convention of Human Rights, Oxford University Press;

Heyns C, Probert, T, (2015) The right to life and the progressive abolition of the death penalty, in: Moving Away from the Death Penalty: Arguments, Trends and Perspectives, 214-227.

Hilaire, Constantine and Benjamin et al. v. Trinidad and Tobago, case 12.269;

Ismaili v. Germany (dec.), app. no. 58128/00;

Luboto v Zambia, Communication No. 390/1990;

Mamatkulov and Askarov v. Turkey [GC], app. nos. 46827/99 and 46951/99;

Maryam Khalilova v. Tajikistan, Communication No. 973/2001;

Ocalan v Turkey, app. no. 46221/99;

Pratt and Morgan v Jamaica, Communication No. 210/1986; 
Pretty v. The United Kingdom, app. no. 2346/02;

Reid v. Jamaica, Communication No. 250/1987;

Report of the Special Rapporteur on extrajudicial, summary or arbitrary executions, E/CN.4/1999/39, (1999);

Report of the Special Rapporteur on the extrajudicial, summary or arbitrary executions, E/CN.4/1997/60, 24. (1996);

Implementation of the safeguards guaranteeing protection of the rights of those facing the death penalty, Resolution 1989/64, The Economic and Social Council, (1989);

Rodley, N, (2015) The death penalty as a human rights issue, in: Moving Away from the Death Penalty: Arguments, Trends and Perspectives, 204-214;

Rrapo v Albania, app. no. 58555/10;

S.R. v. Sweden (dec.), app. no. 62806/00;

Safarmo Kurbanova v. Tajikistan, Communication No. 1096/2002;

Soering v. the United Kingdom, app. no. 14038/88;

Soering v. the United Kingdom, app. no. app. no. 14038/88;

The Question of the Death Penalty, UN Commission on Human Rights, Human Rights Resolution 2005/59, E/CN.4/RES/2005/59, (2005);

CCPR General Comment No. 6: Article 6 (Right to Life), UN Human Rights Committee (HRC), 30 April 1982;

\title{
ДА ЛИ ЧЛАН 2 ЕВРОПСКЕ КОНВЕНЦИЈЕ О ЉУДСКИМ ПРАВИМА ПРЕДСТАВЉА АПСОЛУТНУ ЗАБРАНУ СМРТНЕ КАЗНЕ? - УТИЦАЈ НОВИЈЕ ПРАКСЕ ЕВРОПСКОГ СУДА ЗА ЉУДСКА ПРАВА
}

\author{
Иван Илић, Саша Кнежевић \\ Универзитет у Нишу, Правни факултет, Ниш, Србија
}

\section{Резиме}

Последњих деценија дошло је до тенденције за апсолутним укидањем смртне казне, у доба рата и мира. Та тенденција снажно је подржана од најзначајнијих међународних организација. Као резултат тог настојања, готово све европске државе укинуле су смртну казну. Уз то, Савет Европе усвојио је Протокол 6 и Протокол 13, којим је потпуно укинуо смртну казну. Европски суд је такође у својој пракси, користећи се начелом „конвенција као живи инструмент”, мењао приступ према опсегу забране примене смртне казне. Од првобитног приступа, израженог у случају Soering v UK, који негира аброгацију члана 2, преко случаја Ocalan v Turkey, где је Суд отворио такву могућност, па до случаја Al-Saadon and Mufdhi v the UK, где је Суд експлицитно истакао да је дошло до аброгације става 1 члана 2 Конвенције. Аутори се у раду баве критичким тумачењем праксе Европског суда, покушавајући да одговоре на питање да ли је заиста дошло до аброгације одредбе става 1 члана 2, тако да сада и према тој одредби постоји апсолутна забрана примене смртне казне у државама чланицама Савета Европе. Судећи по образложењу ЕСЉП, тврдимо да се у овом тренутку може рећи да је смртна казна сама по себи кршење права на живот, гарантовано чланом 2 Конвенције, без обзира на то да ли је одређена држава ратификовала Протокол 13. 
Могло би се рећи да је члан 2 Конвенције измењен и допуњен тако да забрањује смртну казну у свим околностима. То значи да је смртна казна, у било којем облику, сада кршење права на живот. Поред тога, изрицање смртне казне несумњиво је у супротности са забраном мучења, нехуманог и понижавајућег поступања. Заједно са аброгацијом члана 2 Конвенције, постоји еволуција концепта права на живот на међународном нивоу. Ова еволуција иде до максиме да се право на живот не може одузети намерно, осим ако се на тај начин не спаси право на живот другог. Таква тенденција, путем међународних прописа, намеће обавезу државама да укину смртну казну. Ова позиција је ојачана важним иницијативама, које су предузеле регионалне организације, које могу играти значајну улогу у промоцији и заштити права на живот широм света. 